\title{
THE TECHNICAL INEFFICIENCY EFFECTS OF TURKISH BANKS AFTER FINANCIAL LIBERALIZATION
}

\author{
NAZMI DEMIR \\ SYED F. MAHMUD \\ SENOL BABUSCU
}

First version received March 2004; final version accepted March 2005

\begin{abstract}
The banking sector in Turkey has grown significantly over the last two decades of financial liberalization. One of the aims of the financial liberalization was to improve efficiency through restructuring programs including the privatization of state banks and the encouragement of mergers. In this paper we identify key factors determining the technical efficiency differentials among Turkish commercial banks in the pre- and post-liberalization periods, using the technical inefficiency effects model. We found that loan quality, size, ownership of the banks, and profitability have a positive and significant impact on the technical efficiencies of banks. The results warrant implementation of effective regulatory measures to improve the quality of the earning assets of commercial banks. Furthermore, steps by the government to encourage acquisitions or mergers for private banks and the privatization of state-owned banks seem to be consistent in improving the overall efficiency of commercial banking in Turkey.
\end{abstract}

Keywords: Technical efficiency; Turkish commercial banks

\section{INTRODUCTION}

$\mathrm{T}$ HE Turkish financial system underwent fundamental changes after the financial liberalization program, which was initiated in 1984. The main objective of these liberalization policies has been to advance towards a freemarket-type economy. The implementation of these policies has also been politically motivated by the desire to become a full member of the European Union. The set of financial policies adopted was primarily aimed at increasing competition in the banking sector. The basic indicators of growth in the banking sector, following the inception of the liberalization program, are presented in Table I. Between 1984 and 1999, the number of banks increased from 47 to 81, branches grew from 6,200 to 7,700 and employment increased by 30 percent. Assets of the banks, in terms of

Any correspondences should be addressed to Nazmi Demir, Department of Banking and Finance, SAL, Bilkent University, 06800 Bilkent, Ankara, Turkey. E-mail: nazmi@ bilkent.edu.tr. 
TABLE I

Structural Changes in the Banking Sector after Financial Liberalization, Turkey

\begin{tabular}{lrrr}
\hline & 1984 & 1999 & $1999 / 1984$ \\
\hline Number of banks & 47 & 81 & 1.72 \\
Number of branches & 6,226 & 7,691 & 1.24 \\
Number of employees & 134,656 & 173,988 & 1.29 \\
Total assets (U.S.\$ million) & 22,678 & 133,533 & 5.89 \\
Noninterest expenses (U.S.\$ million) & 857 & 9,317 & 10.87 \\
Total deposits (U.S.\$ million) & 13,314 & 86,058 & 6.46 \\
Foreign borrowing (U.S.\$ million) & 170 & 12,073 & 71.02 \\
Shareholders' equity (U.S.\$ million) & 1,874 & 3,644 & 1.94 \\
\hline
\end{tabular}

Source: Banks Association of Turkey (TBB) and published balance sheets of banks.

U.S. dollars, showed a 6-fold increase and noninterest expenses, particularly in machinery and equipment for e-banking, expanded by 11 -fold in value. On the financial liabilities side, deposits grew 6.5 times while growth in net worth was at a relatively modest rate of 94 percent (Babuscu 2000). However, one of the most important sources of funds was cheap foreign exchange with an overvalued Turkish lira (TL) at the pegged exchange rates. Banks' foreign exchange borrowings were only U.S. $\$ 0.17$ billion in 1984 , but increased to U.S.\$12.07 billion in 1999, a remarkable 71-fold growth which was mostly invested in government securities. ${ }^{1}$ This explains to some extent why frequent bank failures were reported after the 1994 economic crisis when the TL was heavily devalued (Yeldan 2001).

The growth of the banking sector has been affected by large budget deficits, high rates of interest and inflation, and the inertial nature of the markets. The failures in the banking sector have been explained by the lack of timely prudent regulatory infrastructure to back the liberalization program and the government's reluctance to initiate credible structural reforms (Dervis 2001). The environment encouraged private banks to reap the benefits of high interest rates by lending to the government. The proportion of government securities to the total earning assets of banks rose after the early 1990s, and this was more conspicuous for foreign banks than others (see Figure 1). The crowding out of funds for the private sector provided incentives for groups of corporations to own banks and establish their own capital base.

Frontier analysis has been widely employed to benchmark the relative performance of financial institutions. Berger et al. (1997) have surveyed 130 studies that apply frontier efficiency analysis to financial institutions in 21 countries, employing various parametric and non-parametric estimation methods. Our focus in this paper is to employ stochastic frontier analysis with a technical inefficiency effects (TIE) model to estimate the technical inefficiency differentials of commercial banks

${ }^{1}$ See database of the Türkiye Bankalar Birliği (Banks Association of Turkey, TBB), 2001, Ankara. 
Fig. 1. Proportions of Securities in Income Earning Assets of Depository Banks, Turkey

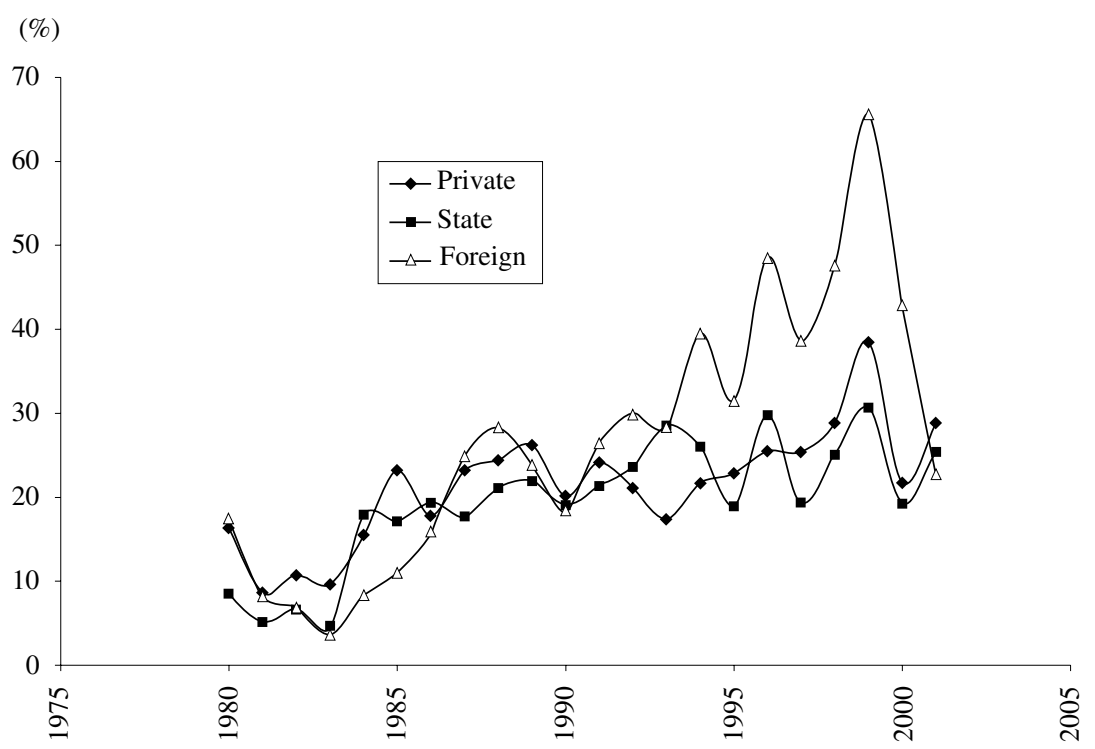

Source: Balance sheets of banks belonging to the Banks Association of Turkey.

in Turkey and to explain these differentials by several bank specific variables. In Section II we present our model, in Section III we discuss the data employed, and in Sections IV and V we present the results and make concluding remarks.

\section{THE MODEL}

Following Huang and Liu (1994), Battese and Coelli (1995), and Battese and Broca (1997), we employ a translog stochastic production frontier with the TIEs of Turkish banks for the pre-liberalization (1981-84) and the post-liberalization (199598) periods. ${ }^{2}$

The model specification, dropping the time subscript, is as follows:

$$
\ln Y_{i}=\beta_{0}+\sum_{j} \beta_{j} \ln X_{j i}+\sum_{j} \sum_{k} \beta_{j k} \ln X_{j k i}+V_{i}-U_{i} .
$$

Output $Y$ is defined as the sum of total loans and securities, and vector $X$ includes: labor $(L)$, deposits $(D)$, borrowed funds $(B)$, and equity $(N W)$. The subscript " $i$ " is for the $i$ th bank $(i=1,2, \ldots, 43)$ and $j, k=L, D, B$, and $N W$. The error term $V_{i}$ is

${ }^{2}$ A survey of bank efficiency studies on the Turkish banking sector shows that our study is the first to employ a stochastic production function with inefficiency effects. Most of the published works on Turkish banking have employed non-parametric methods or cost functions, for example, Zaim (1995), Özkan (1997), Mahmud and Zaim (1998), Aydogan and Capoglu (1989), Cingi and Tarim (2000), Denizer, Dinc, and Tarimcilar (2000), and Altunbas and Chakravarty (2001). 
assumed to be independent and identically distributed as normal random variables with zero mean and constant variance $\sigma_{v}^{2}$, and is also assumed to be independent of $U_{i}$. The other error term, $U_{i}$, is assumed to be non-negative and independently distributed random terms, which are obtained by truncation (at zero) of a normal distribution with variance $\sigma^{2}$ and mean $\mu_{i}$, which is defined as:

$$
\mu_{i}=\delta_{0}+\sum_{m} \delta_{m} Z_{m i}
$$

Equation (2) represents the TIE part of the model. These $Z$-variables include the size of the bank, ratio of loans to total earning assets representing the investment practices of the banks, dummy variables for the ownership status of banks, the rate of return on assets, and the percentage of nonperforming loans (bad debts) in total credits. $^{3}$

\section{DATA}

In assessing technical efficiency in banking studies, two main approaches are being used: the production approach and the intermediary approach (Humphrey 1992). These approaches have implications for inputs and outputs included in the empirical specification of the model. The production approach includes deposit-related services as primary output and treats capital, labor, and other physical resources as inputs. This approach is normally preferred for evaluating the efficiencies of branches of financial institutions (Berger et al. 1997). On the other hand under the intermediary approach, financial institutions are primarily considered as intermediating funds between savers and investors. Therefore it treats deposits as input and loans and other investments as output. In this study we focus on the intermediary approach, which seems more appropriate for evaluating the entire banking sector (Berger et al. 1997; Taylor et al. 1998).

The data employed in this paper have been taken from the publications of the Türkiye Bankalar Birliği (Banks Association of Turkey, TBB). The sample for the pre-liberalization period included 23 commercial banks for the years between 1981 and 1984. The sample was restricted to those years because formats of financial statements changed after 1980 and this format was in use until the year 1984. In 1985 new banking laws were enacted and the process of reforms started. From the 42 banks that existed in 1981, all the non-depository banks and those that were engaged in non-banking activities were excluded from our analyses. ${ }^{4}$ Moreover banks that stopped operating and those that entered the sector during 1981-84 were

\footnotetext{
${ }^{3}$ Studies on bank efficiency have used a wide range of other model specifications and estimation techniques, for example, Kaparakis, Miller, and Noulas (1994); Kraft and Tirtiroglu (1998); English et al. (1993); Berger and DeYong (2001); and Chaffai, Dietsch, and Lozano-Vivas (2001).

4 For example three banks, Sumerbank, Eti Bank, and Denizcilik Bank, were involved in manufacturing consumer goods and reporting these transactions mixed in with banking transactions.
} 


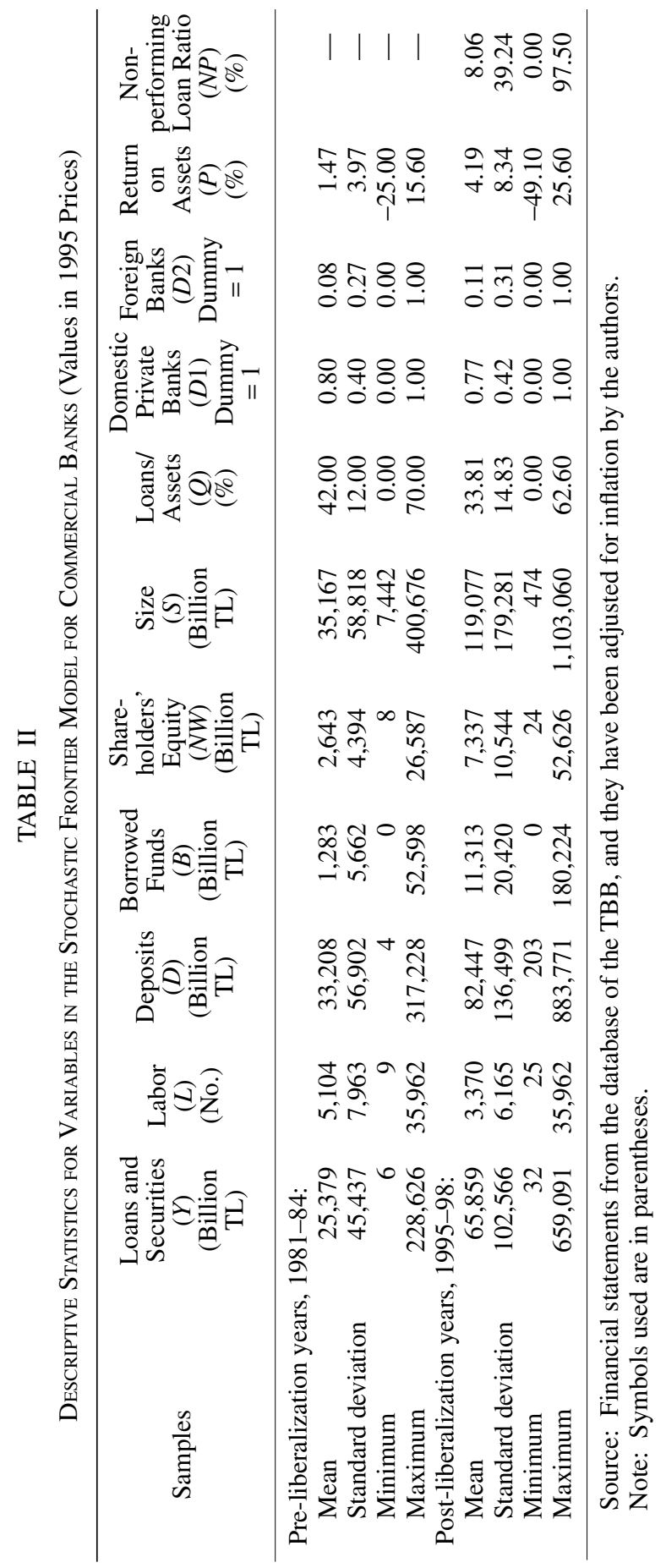


also not included in the sample for consistency and conformity with our post-liberalization sample of banks.

There have been many structural changes in Turkey's banking sector between the years 1985 and 1990. These new regulations and procedures were put into effect in stages. A consistent set of panel data was available for 43 commercial banks for the years 1991-98. The financial sector faced serious crisis in 1999. Many banks declared bankruptcy and several mergers of banks took place. Therefore we have restricted our analysis of the post-liberalization period to the years 1991-98. The data for the more recent years of the post-liberalization period (1995-98) have been employed as a basis for comparison with the pre-liberalization period. We also employed longer post-liberalization data, 1991-98, to examine the consistency of results.

All variables expressed in values are measured at constant 1995 prices. The endogenous variable in our empirical specification is the risk assets of banks measured as loans plus investment in securities. Four inputs: labor, deposits, borrowing, and net worth have been employed. Labor is the total number of employees of the banks. Deposits include both demand and time deposits in local currency. Borrowings are the total external borrowings of the banks. Net worth is bank shareholders' capital. In the TIE part of the model, six Z-variables have been included: size, asset quality, ownership of banks, profitability, and ratio of nonperforming loans. Total assets of banks are used to measure the size of the banks. Asset quality is measured as the ratio of loans to assets. Two dummy variables are included for bank ownership: domestic private banks and foreign banks, where state banks constitute the base. Profitability is the return on assets (ROA) measured as the ratio of after-tax profits to total assets. Finally, the nonperforming loans ratio is the ratio of nonperforming loans to total loans. ${ }^{5}$

A summary of variables for the production frontier and bank-specific variables (Z-variables) for the TIE model is provided in Table II. The mean output (loans plus securities) in real terms has increased from TL25.4 trillion to TL65.9 trillion in over a decade, a 159 percent increase. During the same period, average employment has significantly gone down from 5,104 to 3,370 employees. It appears that automation of the banking industry led to this decrease.

\section{DISCUSSION OF RESULTS}

The parameters of the model in equations (1) and (2) have been simultaneously estimated for the pre-liberalization (1981-84) and post-liberalization (1995-98) periods by using the maximum likelihood method (FRONTIER 4.1 by Coelli 1996). The results are shown in Table III. We also estimated the same model for a longer post-liberalization period (1991-98). The results are reported in the Appendix Table.

5 The banks were not required to report their nonperforming loans in the pre-liberalization period. 
TABLE III

Maximum Likelihood Estimates of the Stochastic Production Frontiers with Bank-Specific Variables, Turkish COMMERcial Banks

\begin{tabular}{|c|c|c|}
\hline Parameters & $\begin{array}{c}\text { Pre-liberalization } \\
\text { 1981-84 }\end{array}$ & $\begin{array}{c}\text { Post-liberalization } \\
\text { 1995-98 }\end{array}$ \\
\hline $\begin{array}{l}\text { Constant } \\
\beta_{L} \text { Labor } \\
\beta_{D} \text { Deposits } \\
\beta_{B} \text { Borrowed funds } \\
\beta_{W} \text { Net worth } \\
\beta_{L L} \\
\beta_{D D} \\
\beta_{B B} \\
\beta_{W W} \\
\beta_{L D} \\
\beta_{L B} \\
\beta_{L W} \\
\beta_{D B} \\
\beta_{D W} \\
\beta_{B W}\end{array}$ & $\begin{array}{r}12.073(0.111)^{* *} \\
0.351(0.130)^{* *} \\
0.204(0.101)^{* *} \\
0.007(0.567) \mathrm{n} \\
0.483(0.122)^{* *} \\
0.041(0.085) \mathrm{n} \\
0.074(0.043)^{*} \\
0.001(0.007) \mathrm{n} \\
0.149(0.020)^{* *} \\
-0.008(0.095) \mathrm{n} \\
0.028(0.019) \mathrm{n} \\
-0.088(0.095) \mathrm{n} \\
-0.032(0.019)^{*} \\
-0.189(0.076)^{* *} \\
0.008(0.015) \mathrm{n}\end{array}$ & $\begin{array}{c}10.948(0.073)^{* *} \\
0.142(0.083)^{* *} \\
0.397(0.061)^{* *} \\
0.191(0.032)^{* *} \\
0.278(0.090)^{* *} \\
0.132(0.115)^{*} \\
0.389(0.059)^{* *} \\
0.046(0.009)^{* *} \\
0.350(0.269) \mathrm{n} \\
-0.146(0.051)^{* *} \\
0.008(0.004)^{* *} \\
-0.017(0.130) \mathrm{n} \\
-0.002(0.0005)^{* *} \\
-0.254(0.076)^{* *} \\
-0.053(0.280) \mathrm{n}\end{array}$ \\
\hline $\begin{array}{l}\text { Constant } \\
\delta_{S} \text { Asset size } \\
\delta_{Q} \text { Loans/assets } \\
\delta_{D 1} \text { Dummy for domestic private banks } \\
\delta_{D 2} \text { Dummy for foreign banks } \\
\delta_{P} \text { Profit percent } \\
\delta_{N P} \text { Nonperforming loan ratio } \\
\sigma_{s}^{2} \\
\gamma \\
\text { Log likelihood function }\end{array}$ & $\begin{array}{c}2.103(0.662)^{* *} \\
-0.000004(0.000003) \mathrm{n} \\
-0.048(0.017)^{* *} \\
0.111(0.356) \mathrm{n} \\
-2.037(0.997)^{* *} \\
0.019(0.029) \mathrm{n} \\
- \\
0.098(0.051)^{* *} \\
0.482(0.293)^{*} \\
-6.60\end{array}$ & $\begin{array}{r}1.793(0.337)^{* *} \\
-0.000003(0.0000)^{*} \\
-0.036(0.006)^{* *} \\
-0.402(0.267)^{* *} \\
-1.050(0.360)^{* *} \\
-0.012(0.007)^{* *} \\
0.005(0.002)^{* *} \\
0.223(0.049)^{* *} \\
0.856(0.054)^{* *} \\
-30.02\end{array}$ \\
\hline
\end{tabular}

Note: The standard errors are given in parentheses.

a Records on nonperforming loans have been reported from the year 1985 and onward.

** , ", and " $\mathrm{n}$ " indicate respectively significance at the 1 percent and 5 percent levels, and nonsignificance.

These results are consistent with the ones reported in Table III for the later postliberalization period (1995-98). We only compare the results of the post-liberalization period (1995-98) with the pre-liberalization period (1981-84) in the text.

Several key hypotheses to establish the significance of the stochastic frontier model and the inefficiency effects model have been tested first. The results of these tests are reported in Table IV. Given the neutral specification of the full model, the hypotheses that the parameters of the TIEs are all zero have been strongly rejected, in all cases, based on the log-likelihood ratio test (Battese and Broca 1997). ${ }^{6}$

${ }^{6}$ A non-neutral Huang model where the interaction of inputs and Z-variables were included in the TIEs was also tried. It was not found significantly different from the neutral model reported in Table III. 
TABLE IV

Tests of Null Hypotheses Based on the Likelihood Ratio Statistic for Parameters of the Stochastic Frontier Production Functions for Turkish Commercial Banks

\begin{tabular}{|c|c|c|c|c|c|}
\hline Null Hypotheses & $\begin{array}{l}\text { Meaning of the Null } \\
\text { Hypotheses }\end{array}$ & $\begin{array}{l}\text { Log } \\
\text { Likelihood } \\
\text { Function }\end{array}$ & $\lambda$ & $\begin{array}{c}\text { Critical } \\
\text { Value at } \\
1 \%\end{array}$ & Decision \\
\hline $\begin{array}{l}\text { Pre-liberalization years, } 1981- \\
\text { Given the neutral translog } \\
\text { model } \\
H_{0}: \delta_{S}=\delta_{Q}=\delta_{D 1}=\delta_{D 2}=\delta_{P}\end{array}$ & $\begin{array}{l}\text { There are no linear TIEs } \\
\text { from bank-specific } \\
\text { variables }\end{array}$ & -6.60 & 67.48 & 15.09 & Reject $H_{0}$ \\
\hline $\begin{array}{l}\text { Post-liberalization years, } 1995 \\
\text { Given the neutral translog } \\
\text { model } \\
\begin{array}{l}H_{0}: \delta_{S}=\delta_{Q}=\delta_{D 1}=\delta_{D 2} \\
=\delta_{P}=\delta_{N P}\end{array}\end{array}$ & $\begin{array}{l}\text { There are no linear } \\
\text { TIEs from bank-specific } \\
\text { variables }\end{array}$ & -30.02 & 62.20 & 16.80 & Reject $H_{0}$ \\
\hline
\end{tabular}

Notes: 1 . We ran non-neutral versions of the models with $Z$-variables $(Z$-variables in linear terms as well as interactions with the $X$-variables), and they are not statistically different than their respective neutral versions. Given the preferred neutral models, Cobb-Douglas functions with and without bank-specific variables were also tried, and both of these restricted forms were rejected based on their respective likelihood ratio.

2. The likelihood ratio is $\lambda=-2 \ln \left(H_{0} / H_{1}\right)$ where $H_{0}$ and $H_{1}$ are the likelihood functions under the null and alternative hypotheses respectively. For chi-square distribution d.f. $=$ number of restricted parameters.

The two null hypotheses that $H_{0}: \gamma=0$ and $H_{0}: \gamma=1$ were also tested. Both the hypotheses have been rejected at the $1 \%$ level of significance (see Table III). We also performed Goldfeld-Quandt and White's general heteroscedasticity test to find evidence of the heteroscedastic error structure. We could not reject the null hypotheses of homoscedasticity at the 5\% level of significance in all the cases. In some cases the null hypothesis could be rejected at the $10 \%$ level of significance. For example the highest calculated $F$-statistic was 1.55 and $F_{40,40,0.05}$ is 1.69 and $F_{40,40,0.1}$ is 1.51. In case of White's general heteroscedasticity test, including all the input variables, the calculated chi-square test statistic was 14.65 while the critical value at the $5 \%$ level of significance was 26.29 with 16 degrees of freedom.

The problem of multicollinearity was also examined. The simple correlation between all variables was below 0.5 except between the deposits and labor variables (0.65). High correlation between these variables was expected. One would expect labor to cause higher deposits as well. However our model follows the intermediary approach where deposits are treated as one of the inputs (see Section II for more details). Most of the estimated parameters of the stochastic production function and 


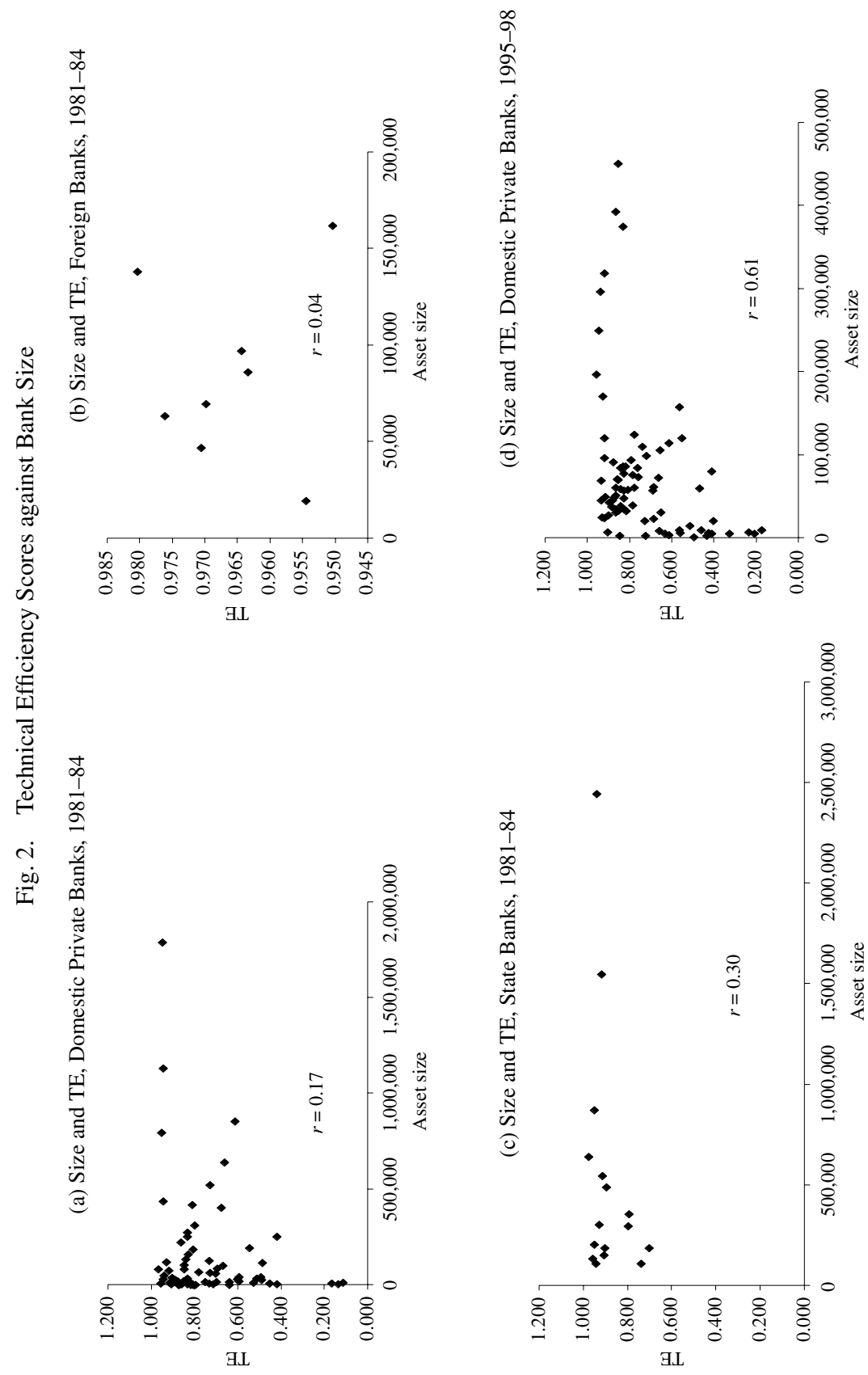


TURKISH BANKS
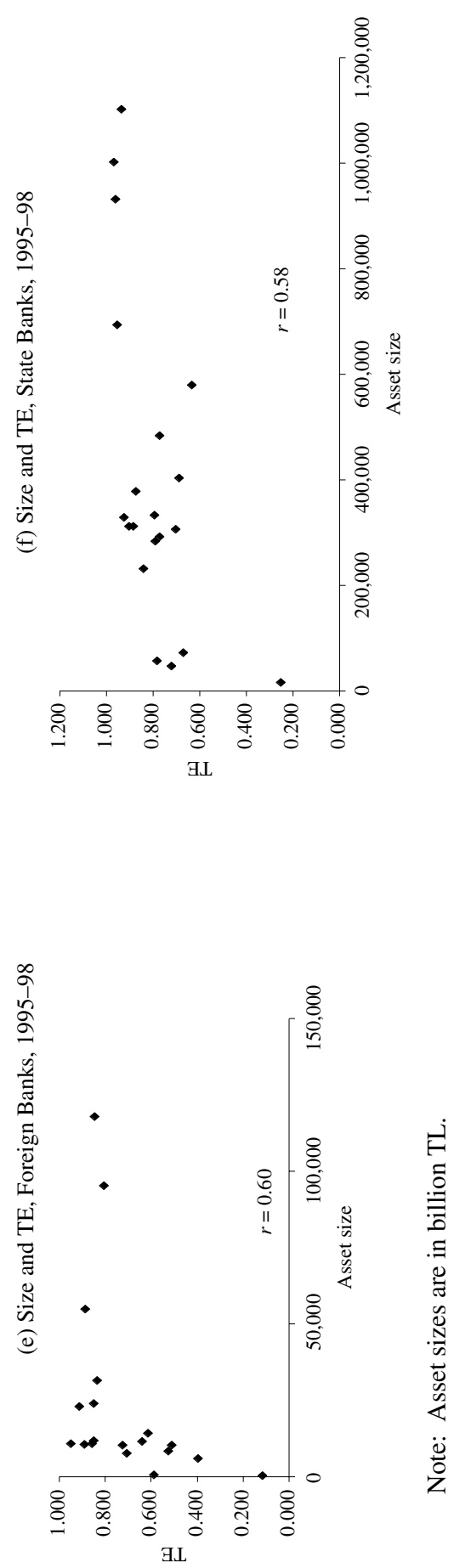


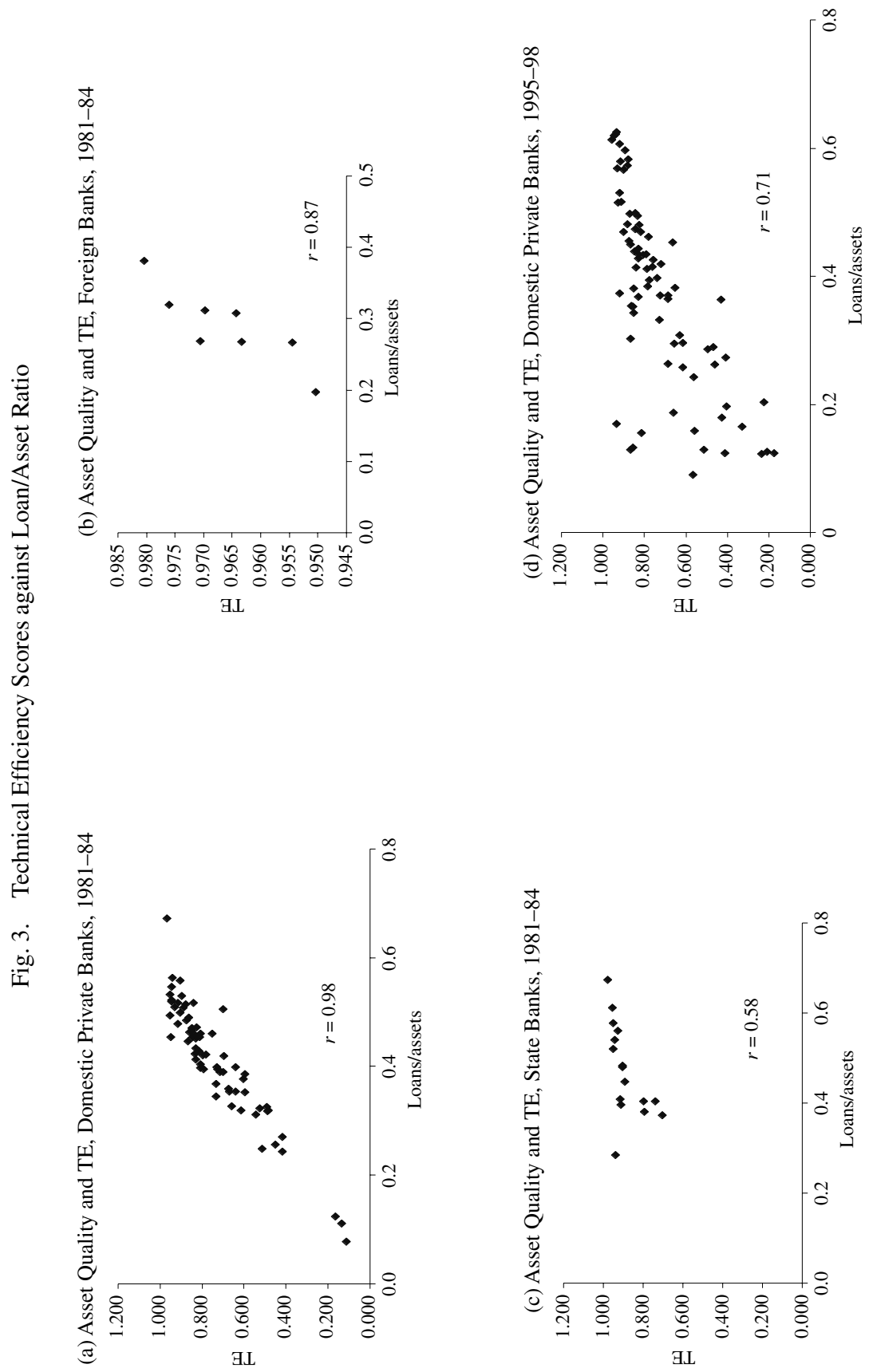



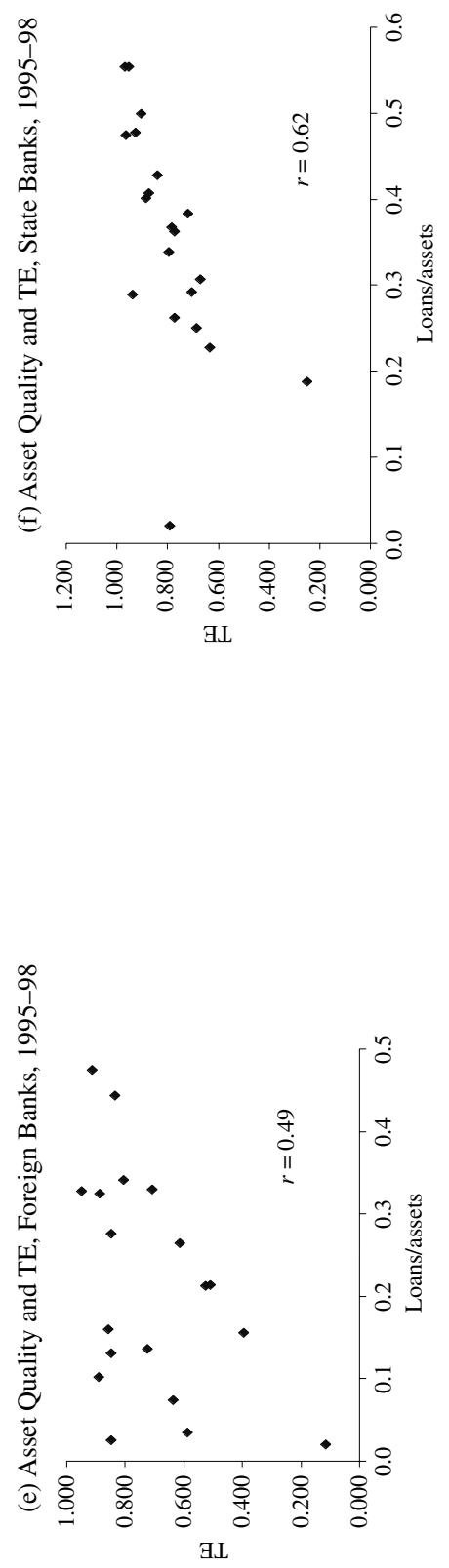
of the inefficiency effects model have been found to be significantly different from zero (see Table III).

All the estimated output elasticities, except the output elasticity of borrowed funds in the pre-liberalization period, are positive and statistically significant. The input variables employed in the estimation are mean corrected, and therefore the first order parameters of the model are output elasticities evaluated at sample means. The results suggest that the contribution of labor to output did decrease in the postliberalization period. One possible explanation could be the heavy automation of the banking industry and a significant increase in the contribution of borrowed funds in the post-liberalization period. We also tested the null hypothesis of constant returns to scale, $\left(H_{0}: \beta_{L}+\beta_{D}+\beta_{B}+\beta_{W}=1\right)$, using a $t$-test. We could not reject the null hypothesis at the $5 \%$ level of significance. This result may suggest constant returns to scale both in the pre- and post-liberalization periods.

The estimated parameters of the TIE model were all significantly different from zero in the post-liberalization period. In the pre-liberalization period, only two parameters $\left(\delta_{Q}\right.$ and $\left.\delta_{D 2}\right)$, related to asset quality and the dummy variable for foreign ownership respectively, were significant (see Table III).

The larger banks do seem to be more efficient in the post-liberalization period. This result may explain several mergers of commercial banks in the post-liberalization period. Furthermore, the low variability and the range of variable size in the pre-liberalization period (see Table II) could explain the statistical insignificance of the parameter $\delta_{s}$. This result has been further explored by plotting technical efficiency (TE) scores against the size of banks for the three ownership types separately (see Figure 2). We observe that, in the post-liberalization period, the small private commercial banks (up to a total asset of TL 200,000 billion in 1995 prices) have an average efficiency score of $70 \%$ with a standard deviation of $29 \%$, in contrast to the larger banks that average considerably higher, $87 \%$, with a clear convergence represented by a much smaller standard deviation of $10 \%$.

The loans-assets ratio turned out to be significant in both the periods. This result would suggest that banks that have been involved in the more traditional and prudent banking practice of lending money to investors are efficient. Furthermore, in all three types of ownership, we see a direct relationship between the loans-assets ratio and the estimated TE scores. In the case of private commercial banks, not only do the TE scores increase with the ratio, but the variation in scores also declines quite significantly for banks with a high loans-assets ratio (see Figure 3).

The ownership of banks also seems to affect technical efficiency. On average, private and foreign banks are more efficient than public banks in the post-liberalization period. The state banks seem to be more efficient in the pre-liberalization period, but the coefficient is not statistically significant. This is consistent to some extent with the results reported in Zaim (1995), ${ }^{7}$ where state banks were reported as 7 Zaim (1995) reported that the state banks were more efficient than private banks. 
more efficient in the pre-liberalization period. The results also indicate that banks with higher profitability are also technically more efficient in the post-liberalization period. The result for the pre-liberalization period was not statistically significant. Finally, as expected, banks with a higher nonperforming loan ratio turned out to be less efficient in the pre-liberalization period.

\section{CONCLUDING REMARKS}

In this paper we estimated the stochastic frontier production model with the TIE model for commercial banks in Turkey during the pre-liberalization period (198184) and post-liberalization period (1995-98). First, we used the loans-assets ratio to proxy the investment behavior of banks. We found that banks with a higher loansassets ratio are more technically efficient as opposed to the securities-oriented banks, both in the pre- and post-liberalization periods. This result seems to be consistent with a general observation that in Turkey many banks entered the banking sector solely to reap short-run profits by lending money to the government under highly inflationary conditions with a high real rate of interest on treasury bills. The result also suggests that banks with low ratios have large variations in their technical efficiency scores.

Second, bank size also turned out to be a significant determinant of technical efficiency in the post-liberalization period. The result may imply that the Turkish government should encourage mergers of smaller private commercial banks to gain efficiency in the sector. Third, private and foreign banks are found to be technically more efficient compared to state-owned banks. In the pre-liberalization period, however, this distinction was not so evident. This result supports the current policy of the Turkish government to continue with privatization efforts. Finally, we found that banks with higher rates of profitability are also more efficient, implying that profitability can be compatible with technical efficiency.

\section{REFERENCES}

Altunbas, Y., and S. P. Chakravarty. 2001. "Frontier Cost Functions and Bank Efficiency." Economic Letters 72, no. 2: 233-40.

Aydogan, Kursat, and Gokhan Capoglu. 1989. "Bankacilik sistemlerinde etkinlik ve verimlilik: Uluslarası bir karsilastirma" [Efficiency and productivity in banking systems: An international comparison]. National Productivity Center Report no. 397. Ankara: Milli Produktivite Merkezi.

Babuscu, Senol. 2000. “Turk bankacilik sektorunde risk yönetimi, Turkiye ic denetim enstitusu, risk yönetimi, ic denetim ve teknoloji entegrasyonu paneli” [Management of risk in the banking sector, the institute of internal auditing and risk management]. Paper presented at the panel organized by the Institute of Internal Auditing, May 2000, Istanbul.

Battese, George E., and Sumiter S. Broca. 1997. "Functional Forms of Stochastic Frontier 
Production Functions and Models for Technical Inefficiency Effects: A Comparative Study for Wheat Farmers in Pakistan.” Journal of Productivity Analysis 8, no. 4: 395414.

Battese, George E., and T. J. Coelli. 1995. "A Model for Technical Inefficiency Effects in a Stochastic Frontier Production Function for Panel Data.” Empirical Economics 20, no. 2: $325-32$.

Berger, Allen N.; P. L. Brockett; W. W. Cooper; and J. T. Pastor. 1997. "New Approaches for Analyzing and Evaluating the Performance of Financial Institutions." European Journal of Operational Research 98, no. 2: 170-74.

Berger, Allen N., and Robert DeYoung. 2001. "The Effects of Geographic Expansion on Bank Efficiency.” Journal of Financial Services Research 19, nos. 2-3: 163-84.

Chaffai, Mohamed E.; Michel Dietsch; and Ana Lozano-Vivas. 2001. "Technological and Environmental Differences in the European Banking Industries." Journal of Financial Services Research 19, nos. 2-3: 147-62.

Cingi, S., and S. A. Tarim. 2000. "Turk banka sisteminde performns olcumu: DEAMalmquist TFP endeksi uygulaması" [Measuring the performance of the Turkish banking system: DEA — application of the Malmquist total factor productivity index]. Türkiye Bankalar Birliği arastırma tebligleri serisi [Banks Association of Turkey research series] no. 2001-01. Istanbul: Banks Association of Turkey.

Coelli, T. J. 1996. "A Guide to FRONTIER Version 4.1: A Computer Program for Stochastic Frontier Production and Cost Function Estimation." CEPA Working Paper no. 96/7. Armidale: Department of Econometrics, University of New England.

Denizer, Cevdet A.; Mustafa Dinc; and Murat Tarimcilar. 2000. “The Impact of Financial Liberalization on the Efficiency of the Turkish Banking System: A Two-Stage DEA Application." Working Paper Series no. 2000-02. Ankara: Banks Association of Turkey.

Dervis, K. 2001. Statement of Minister of State in charge of economic affairs, at press conference held on March 19, Ankara.

English, M.; S. Grosskopf; K. Hayes; and S. Yaisawarng. 1993. "Output Allocative and Technical Efficiency of Banks.” Journal of Banking and Finance 17, nos. 2-3: 349-66.

Huang, Cliff J., and Jin Tan Liu. 1994. "Estimation of a Non-neutral Stochastic Frontier Production Function.” Journal of Productivity Analysis 5, no. 2: 171-80.

Humphrey, David B. 1992. "Flow versus Stock Indicators of Banking Output: Effects on Productivity and Scale Economy Measurement." Journal of Financial Services Research 6, no. 2: 115-35.

Kaparakis, Emmanuel I.; Stephen M. Miller; and Athanasios G. Noulas. 1994. "Short-Run Cost Inefficiency of Commercial Banks: A Flexible Stochastic Frontier Approach.” Journal of Money, Credit, and Banking 26, no. 4: 875-93.

Kraft, Evan, and Dogan Tirtiroglu. 1998. "Bank Efficiency in Croatia: A Stochastic Frontier Analysis." Journal of Comparative Economics 26, no. 2: 282-300.

Mahmud, Syed F., and Osman Zaim. 1998. "Cost Structure of Turkish Private Banking Industry: A GL Restricted Cost Function Approach.” Middle East Technical University Studies in Development 25, no. 3: 435-46.

Özkan, Günay. 1997. "Measuring Cost Efficiency for Turkish Commercial Banks: The Stochastic Cost Frontier Approach." Review of Social, Economic and Administrative Studies 11, nos. 1-2: 189-210.

Taylor, William M.; Russell G. Thompson; Robert M. Thrall; and P. S. Dharmapala. 1998. "DEA/AR Efficiency and Profitability of Mexican Banks: A Total Income Model." European Journal of Operational Research 98, no. 2: 346-64. 
Yeldan, Erinc. 2001. Kuresellesme surecinde Türkiye ekonomisi, bolusum, birikim ve buyume [The Turkish economy, allocation, accumulation, and growth during globalization]. Istanbul: Iletisim Yayinlari.

Zaim, Osman. 1995. "The Effect of Financial Liberalization on the Efficiency of Turkish Commercial Banks.” Applied Financial Economics 5, no. 4: 257-64.

\section{APPENDIX TABLE}

Maximum Likelihood Estimates of the Stochastic Production Frontier with and without Bank-Specific Variables in the Post-liberalization Period, 1991-98, FOR TURKISH COMMERCIAL BANKS

\begin{tabular}{|c|c|c|}
\hline Parameters & Without $Z$-Variables & With $Z$-Variables \\
\hline Constant & $11.205(0.047)^{* * *}$ & $11.373(0.073)^{* *}$ \\
\hline$\beta_{L}$ Labor & $0.281(0.046)^{* *}$ & $0.286(0.051)^{* *}$ \\
\hline$\beta_{D}$ Deposits & $0.496(0.045)^{* *}$ & $0.391(0.052)^{* *}$ \\
\hline$\beta_{B}$ Borrowed funds & $0.179(0.026)^{* *}$ & $0.128(0.027)^{* * *}$ \\
\hline$\beta_{W}$ Net worth & $0.037(0.035) \mathrm{n}$ & $0.030(0.034) n$ \\
\hline$\beta_{L L}$ & $0.046(0.008)^{* *}$ & $0.0448(0.008)^{* *}$ \\
\hline$\beta_{D D}$ & $0.047(0.009)^{* * *}$ & $0.035(0.009)^{* *}$ \\
\hline$\beta_{B B}$ & $0.008(0.006) n$ & $0.0040(0.006) n$ \\
\hline$\beta_{W W}$ & $-0.002(0.005) \mathrm{n}$ & $-0.001(0.006) n$ \\
\hline$\beta_{L D}$ & $-0.059(0.018)^{* *}$ & $-0.061(0.017)^{* *}$ \\
\hline$\beta_{L B}$ & $-0.019(0.011)^{*}$ & $-0.013(0.011) n$ \\
\hline$\beta_{L W}$ & $-0.013(0.010)^{*}$ & $-0.008(0.010) n$ \\
\hline$\beta_{D B}$ & $-0.014(0.005)^{* *}$ & $-0.007(0.006)^{*}$ \\
\hline$\beta_{D W}$ & $0.026(0.010)^{* *}$ & $0.020(0.010)^{*}$ \\
\hline$\beta_{B W}$ & $-0.005(0.007) \mathrm{n}$ & $-0.008(0.007) n$ \\
\hline Constant & $24.572(23.677) n$ & $2.029(0.355)^{* * *}$ \\
\hline$\delta_{S} \quad$ Asset size & - & $-5.6 \mathrm{E}-06(0.000)^{* *}$ \\
\hline$\delta_{Q}$ Loans/assets & - & $-0.020(0.003)^{* *}$ \\
\hline$\delta_{D 1}$ Dummy for domestic private banks & - & $-0.709(0.336)^{*}$ \\
\hline$\delta_{D 2}$ Dummy for foreign banks & - & $-0.501(0.318)^{*}$ \\
\hline$\delta_{P}$ Profit percent & - & $-0.009(0.006)^{*}$ \\
\hline$\delta_{N P}$ Nonperforming loan ratio ${ }^{\mathrm{a}}$ & - & $0.002(0.001) n$ \\
\hline$\sigma_{s}^{2}$ & 9.109 (8.479)n & $0.415(0.052)^{* * *}$ \\
\hline$\gamma$ & $0.981(0.019)^{* * *}$ & $0.792(0.051)^{* *}$ \\
\hline Log likelihood function & -268.40 & -226.16 \\
\hline
\end{tabular}

Note: The standard errors are given in parentheses.

${ }^{a}$ Records on nonperforming loans have been reported from the year 1985 and onward. **, ", and " $\mathrm{n}$ " indicate respectively significance at the 1 percent and 5 percent levels, and nonsignificance. 